\title{
Operational Assessment of Public Transport: A Case of Kathmandu, Nepal
}

\author{
Anjay Kumar Mishra ${ }^{1}$, Ram Chandra $\operatorname{Sah}^{2} \&$ P. S. Aithal ${ }^{3}$ \\ ${ }^{1}$ Associate Professor, Madan Bhandari Memorial Academy Nepal, Urlabari 3, Morang, \\ Nepal \\ OrcidID: 0000-0003-2803-4918; Email: anjaymishra2000@gmail.com \\ ${ }^{2}$ Engineer, Shambhunath Municipality, Local Government of Nepal \\ Email: errcsah@gmail.com \\ ${ }^{3}$ Professor, College of Management \& Commerce, Srinivas University, Mangalore, India \\ OrcidID: 0000-0002-4691-8736; E-mail: psaithal@gmail.com
}

Area of the Paper: Business Management.

Type of the Paper: Case Analysis.

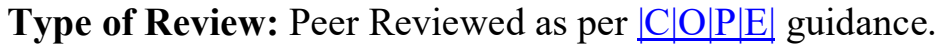

Indexed In: OpenAIRE.

DOI: http://doi.org/10.5281/zenodo.4033197.

Google Scholar Citation: IJCSBE.

\section{How to Cite this Paper:}

Mishra, Anjay Kumar, Sah., Ram Chandra, \& Aithal, P. S. (2020). Operational Assessment of Public Transport: A Case of Kathmandu, Nepal. International Journal of Case Studies in Business, IT, and Education (IJCSBE), 4(2), 132-152.

DOI: http://doi.org/10.5281/zenodo.4033197.

International Journal of Case Studies in Business, IT and Education (IJCSBE)

A Refereed International Journal of Srinivas University, India.

(C) With Authors.

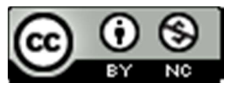

This work is licensed under a Creative Commons Attribution Non-Commercial 4.0 International License subject to proper citation to the publication source of the work.

Disclaimer: The scholarly papers as reviewed and published by the Srinivas Publications (S.P.), India are the views and opinions of their respective authors and are not the views or opinions of the S.P. The S.P. disclaims of any harm or loss caused due to the published content to any party. 


\title{
Operational Assessment of Public Transport: A Case of Kathmandu, Nepal
}

\author{
Anjay Kumar Mishra ${ }^{1}$, Ram Chandra $\mathrm{Sah}^{2}$ \& P. S. Aithal ${ }^{3}$ \\ ${ }^{1}$ Associate Professor, Madan Bhandari Memorial Academy Nepal, Urlabari 3, Morang, \\ Nepal \\ OrcidID: 0000-0003-2803-4918; Email: anjaymishra2000@gmail.com \\ ${ }^{2}$ Engineer, Shambhunath Municipality, Local Government of Nepal \\ Email: errcsah@gmail.com \\ ${ }^{3}$ Professor, College of Management \& Commerce, Srinivas University, Mangalore, India \\ OrcidID: 0000-0002-4691-8736; E-mail: psaithal@gmail.com
}

\begin{abstract}
In absence of the railway at Kathmandu, Nepal, public transport effectiveness needs to be assessed. The paper aims to assess the operational performance of public transportation in Kalanki-Kalimati-Tripureshwor-Bhotahity forward $6700 \mathrm{~m}$ and backward $6200 \mathrm{~m}$ section of Kathmandu. Key Performance Indicators (KPI) for performance assessment were listed from the literature review and finalized through departmental expert consultation based on average mean score analysis of availability, cost of collection, quality and necessity of the data. Based on the finalized 4 KPI along with 29 micro KPI, performance of SajhaYatayat, bus and microbus were compared categorizing under economical, service, safety and people perception by collecting data through field survey. The economic analysis reveals that microbus has the highest internal rate of return and benefit cost ratio highest as $28.55 \%$ and 1.35 respectively while the bus has the highest revenue per kilometer and cost per kilometer as 104.94 and 79.012 respectively. Service indicators analysis reveals that SajhaYatayat has the highest travel time ratio and running time as $1425 \mathrm{sec}$ and 1.66 , microbus has the highest journey time as $1555.86 \mathrm{sec}$, the bus has the highest running speed, journey speed and running index as $17.39 \mathrm{kph}, 16.42 \mathrm{kph}$ and 0.68 while traveling from Kalanki to Bhotahity respectively. The average passenger waiting index is 0.88 . The affordability index of microbus is $4.47 \%$ respectively. Bus punctuality of SajhaYatayat is non-frequent but bus and microbus are Frequent. According to a schedule questionnaire survey with 94 respondents, the result of people perception indicators reveals that $21.27 \%$ of respondents are not satisfied with SajhaYatayat, bus and microbus. It is concluded that SajhaYatayat is performing better among three-selected public transport in the study route i.e. SajhaYatayat, bus and microbus are performing in decreasing order.
\end{abstract}

Keywords: Peakhour, performance, SajhaYatayat, bus, microbus, Economic, service, safety and perception.

\section{INTRODUCTION :}

Transportation is in operation through road and air in Nepal. There is an absence of satisfactory data and arranging system to control leaders, bringing about numerous urban areas choosing wrong modes dependent on those utilized in created nations or letting private administrators to choose. Developing nations have different scenario from those in developed nations and arrangements, explicit to their own requirements rather than just duplicating approaches utilized by those nations, where rail organize is sufficient in contrast with our nation. 
The obligation of the government to guarantee the operations to address the issues of the networks they guide Decision makers critically need to settle for the correct operational choices for the advancement of Road Transportation. Exact and applicable Key Performance Indicators (KPI) and insights will give an away from of operation transportation of Kathmandu and will assist with checking the advantages of working proficient open vehicle modes. Developing a set of appropriate KPI to assess and compare public transport systems is most.

Kalanki-Kalimati-Tripureshwor-Bhotahity is one of the major road sections of Kathmandu valley. To analyze the operation of the public transport systems of the Kathmandu, it needs an appropriate set of KPI understanding the weakness to improve. Transport is the backbone of urban life though there are no performance measures tools to assess public transport operation in this locality. It is impossible to assess the operation of transportation today in absence of performance measures tools. There is also a need for a benchmark for KPIs value to operate public transport.

The flow of traffic in most urban regions has been drastically like the same at the occasions when pony and carriage were the quickest methods for movement portray lackluster showing of existing transport administration in many creating nations by saying open transport in numerous spots misses the mark concerning the request and such systems need complete updating (Parthasarathi et al., 2013) [1]. Kathmandu is not an exception, which rationalized to assess the status. It is significant for decision maker of transportation to get an appropriate set of KPIs to assess and compare the operation of transport. Result of KPIs value help to make a right decision for our locality to improve. Stakeholder of existing public transportation will know the level of self-performance and try to provide better service by removing their weakness and make plan for existence. The traveler of public transport will get to know about the performance of existing public transportation and feel easy to choose to get better service at same condition.

Operation Assessment with help KPIs of public transportation diagnosis real condition of public transport in detail and reveals cause of weakness clearly. The result of KPIs of selected public transportation in the operation area gives benchmark for real economic status, service, safety and people perception.

\section{OBJECTIVE :}

The research aims to assess the operation of selected modes of public transport during peak hour of Kalanki-Kalimati-Tripureshwor-Bhotahity road section.

\section{LITERATURE REVIEW:}

\section{Modes of Public Transportation operated in Kathmandu Valley}

There have plenty of public vehicles travelling within Kathmandu valley. Public transport system is mainly managed by private Sector that operates buses, microbuses, minibuses, tempos and taxies. SajhaYatayat is only cooperative public transportation in Nepal.

\section{SajhaYatayat}

SajhaYatayat is a helpful open transportation association that set up in 1961/1962 to give effective and moderate open transportation in Kathmandu Valley. Its first objective is giving sheltered, productive, solid urban transport inside Kathmandu Valley, in accordance with its momentary destinations.

The current arrangement of the SajhaYatayat is that, the absence of coordination just as the nonappearance of openly claimed transport transportation to set the standard has implied that general society has not served ideally. Administrations urgently need to improve, regarding booking, dependability, reasonableness, Security and solace. Exceptional endeavors must unveil transport all the more effectively open to the impeded, ladies, the old and children. They are likewise under the discussion for the point as human asset improvement, income assortment and checking, transport segment of street streamlining, comprehensiveness and handicap neighbourly open vehicle, collaboration with the private Sector through 'grouping', making arrangements for Bus Rapid Transit (BRT, etc (SajhaYatayat, 2011) [2].

\section{Local bus}

Nearby transports are accessible for short and longer excursions too. These are the least expensive methods for transport for landlocked nation. All the nearby transports of Kathmandu, withdraws from 
Gongabu Bus Park in Ring Road north side of the city at various spans. These are apparently the least expensive method of transportation in Nepal however are excessively packed and not comfort. A few transports won't move until full to a specific standard (Pandey, 2014) [3].

\section{Microbus}

A microbus is a large van or a small bus, depend which way you look at it. It has twenty-three seating capacity including driver. Frequency of microbus is very high in Kathmandu valley (Pandey, 2014) [3].

Tempo

This is a three-wheeled gas powered vehicle for 10-13 passengers. Tempos ply on fixed section of roads at regular intervals. They run in different section of roads around the city (Pandey, 2014) [3].

\section{Paratransit}

Paratransit is the little traveler transport vehicles that work casually. There are no planned administrations and for the most part charges are not fixed. Paratransit administrations have gotten famous since they have filled the hole where formal open vehicle administrations didn't stay aware of the developing traveler request. Paratransit for the most part comprises of minibus-taxis and shared taxicabs (Roux, 2013) [4].

\section{Public Transport Modes Operational Capacity}

A significant thought is the most suitable vehicle size to fulfill the need of traveler transport along a passageway. Large transports and small vehicles are suitable in various conditions and arranging should be completed to decide if a few small vehicles or an enormous vehicle would meet the necessities of travelers and administrators all the more productively. According to Tranter (2013) [6], a bus statics determines the comfort for planner where as Odufuwa and Olufemi (2012) [7] highlighted the need for gender safety for comfort ability along with measuring public transport accessibility were highly focused (Anon, 2010) [8].

Table 1: Modes capacity of Public Transport

\begin{tabular}{|c|c|c|c|}
\hline Mode & Location & $\begin{array}{c}\text { Max passenger flow } \\
\text { per day }\end{array}$ & Survey from \\
\hline SajhaYatayat & $\begin{array}{l}\text { Swoyambhunath to TIA and } \\
\text { Lagankhel to bus park }\end{array}$ & 650 & SajhaYatayat \\
\hline Bus & $\begin{array}{l}\text { Not applicable to a specific } \\
\text { location }\end{array}$ & 350 & SanyuktaYatayat \\
\hline Microbus & $\begin{array}{l}\text { Not applicable to a specific } \\
\text { location }\end{array}$ & 255 & ThankotYatayat \\
\hline Tempo & $\begin{array}{l}\text { Not applicable to a specific } \\
\text { location }\end{array}$ & 128 & Tempo driver \\
\hline Taxi & $\begin{array}{l}\text { Not applicable to a specific } \\
\text { location }\end{array}$ & $5-15$ & Taxi driver \\
\hline
\end{tabular}

\section{Selected Performance Indicators}

Based on availability of data, cost of collection of data, data quality and necessity, the following indicators were found to be applicable for operational performance assessment.

\section{Economic Indicators}

The incentive in utilizing monetary techniques is to appraise how much advantage or return associations get from starting speculations. From these assessments, associations can settle on better choices about financial plan and human asset designation. The consequences of monetary strategies normally show that financial status of the open vehicle. Evaluation techniques that is accessible to gauge huge numbers of the financial aspects of an association. Major practical terms is utilized in efficient examination as speculation, fixed cost, variable cost, rescue esteem, life period, loan fee, annuity, advantage and Scrap esteem.

\section{Benefit Cost Ratio}

Benefit cost ratio is characterized as the proportion of income to cost, which can be given as, 


$$
\text { Benefit cost ratio }=\frac{\text { Benefit (Revenue) }}{\text { Cost }}
$$

It assures that the income to cost proportion to be between 1.05:1 to $1.08: 1$ for the framework to operate effectively (Wright et al. 1987) [9].

\section{Rate of Return}

Major indicator of the financial analysis is internal rate of return (IRR) which communicates as a rate proportion of task execution and valuable instrument to gauge monetary degree of the administration or undertaking. IRR is the rebate rate that conveys a zero NPV on a given undertaking. Limiting, such as intensifying incomes, accept that the underlying venture, yet in addition the net money created by an undertaking, is reinvested inside the task as it continues. Subsequently, the IRR is additionally the venture/reinvestment rate that a task creates over its lifetime - and henceforth IRR is otherwise called the 'financial yield' on a speculation (Ryan, 2008) [10].

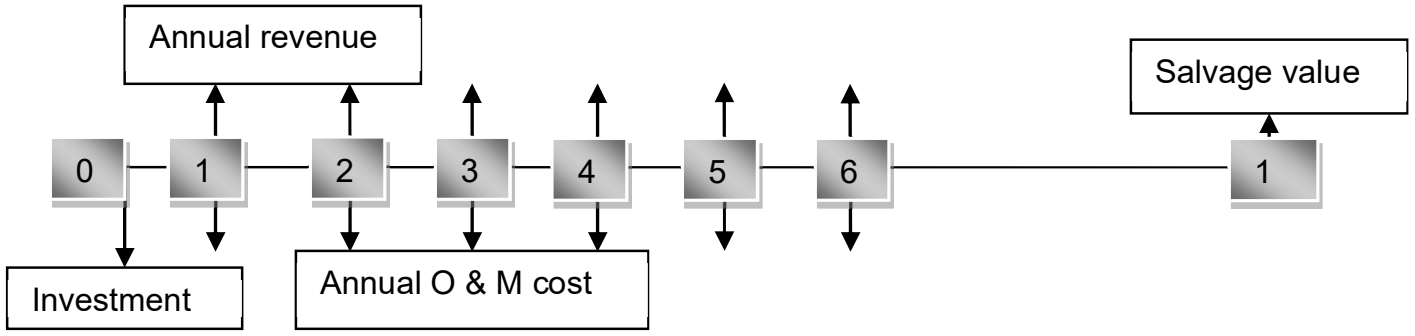

Fig.1: Cash flow diagrams

\section{Service indicators}

\section{Running Time}

Running time and delay studies-A Running time study decides the measure of time needed to make a trip starting with one point then onto the next on a given segment of street. In directing such an investigation, data may likewise be gathered on the areas, length and reasons for delays. At the point when this is done, the investigation is known as a Running time and delay study (Wright et al.1987) [9].

\section{Journey Time}

Journey Time is the absolute time spent to arrive at a destination from a given origin. It incorporates the strolling time, holding up time, on vehicle time and strolling to the objective. It ought not to be more than $2 / 3$ hours out of each day. Unreasonable excursion time reflects lacking transport flexibly or helpless planning or steering (Wright et al.1987) [9].

\section{Running Speed}

The Running speed of commercial buses is the average running speed in section of road.

\section{Journey Speed}

$$
\text { Running speed }=\frac{\text { Length of section of road }}{\text { Running time }}=\frac{\text { Length of section of road }}{\text { Jouney time }- \text { Delay time }}
$$

Journey speed determined based on the ratio of length to time including delays and stoppers.

$$
\text { Journey speed }=\frac{\text { Length of section of road }}{\text { Total journey time including delay }}
$$

In dense areas, journey speed ought to be at least 10-to-12 kph and in transport just paths, 15-to-18 $\mathrm{kph}$. In medium-to low-dense territories, journey speed of around $25 \mathrm{kph}$ ought normal.

In Tunis, the excursion speeds for transports are $14 \mathrm{kph}$ for urban administrations, $19 \mathrm{kph}$ for short rural administrations, and $30 \mathrm{kph}$ for long rural administrations. In the urban zone of Bogota, venture speeds for transports normal 25-to-30 kph however drop to $7 \mathrm{kph}$ for a short bustling Section of the Central Business District. In Cairo, where traffic conditions are especially terrible transport venture rates can differ somewhere in the range of three and $13 \mathrm{kph}$. Diverse excursion velocities can be normal in the pinnacle and off-top periods. In Kuala Lumpur, venture speeds have been recorded at $15 \mathrm{kph}$ during the pinnacle time frame and $25 \mathrm{kph}$ in the off-top. The genuine outcomes will be needy more on traffic and street conditions than on the effectiveness (Wright et al.1987) [9]. 


\section{Travel Time Ratio}

Travel Time Ratio (TTR): The movement time proportion, characterized as the movement time by open vehicle partitioned by movement via vehicle between a similar cause and objective. The proportion vacillates from 1 to 5 for most excursions and by and large, the bigger the proportion, the less serious open vehicle is considered (Kumar et al., 2013) [11].

Travel Time Ratio can be given as

\section{Running Index}

$$
\text { Travel Time Ratio }=\frac{\text { Travel time by public transport }}{\text { Travel time by car }}
$$

Running file (RI) is characterized as the proportion of all out help time to the absolute travel time. As RI expands, productivity of the framework diminishes. It's worth can be fixed somewhere in the range of 0 and 1. For travelers' fulfillment, it's worth can be fixed somewhere in the range of 0.15 and 0.75 relying on the quantity of traveler boarding and landing at various hours of the day (Kumar et al., 2013) [11].

Running file can be given as,

\section{Passenger Waiting Index}

$$
\text { Running index }=\frac{\text { Total service time }}{\text { Total travel time }}
$$

The passenger waiting index (PWI) is the proportion of mean traveler holding up an ideal opportunity to the recurrence of the vehicle administration. The PWI worth can be fixed somewhere in the range of 0 and 1 if the traveler holding back to be boarded ought to be equivalent or not exactly the space accessible in the vehicle administration. Basically, zero worth is preposterous (Kumar et al., 2013) [11]. Passenger waiting index can be given as,

\section{Affordability Index}

$$
\text { Passenger Waiting Index }=\frac{\text { Mean passenger waiting time }}{\text { Frequency of transport service }}
$$

An affordability index could be characterized as the expenditure out of earning. The list would be registered for different pay gatherings and the outcomes examined with a receptive outlook concerning in the case of, utilizing the proof of the extent on pay spent on travel, they are sensible, high or cumbersome. The information on moderateness lists for a similar city at some other point in time, or for different urban areas in a similar nation or somewhere else, may give a valuable premise to comparison. The improvement of an Affordability Index is proposed to reveal more insight into the effect of this incomprehensible circumstance, especially on the conceivable unreasonable distributional impacts on the extremely poor.

The World Bank created affordability index about 10 years back. Carruthers et al (2005 as cited in Abreha, 2007) [12] built up the moderateness list that depends on the movement review way to deal with transport consumption. Moderateness Index can be determined as Affordability Index = Number of trips*Average cost per trip

$$
\text { Per Capita income }
$$

It is expressed as a \%.

Assessing estimations of the Affordability Index requires four snippets of data a lot of urban areas for which the estimations of the record are to be assessed, the income level, the amount of movement on which the movement cost is to be based, and the fare level. Per capita income (Average or Bottom Quintile). According to Turner (2013) [13], required data are as per the following:

Locate the normal per capita month to month pay and the normal for the base quintile of the pay dispersion, for the city;

Decide the base open vehicle passage to travel $10 \mathrm{~km}$ utilizing an everyday ticket

Compute the expense for 60 trips at the fare;

Express this expense as a percent of the normal and base quintile month to month livelihoods

\section{Bus Punctuality}

Bus punctuality insights give one proportion of the local bus service. They depend on information revealed by nearby specialists who screen dependability either utilizing manual overviews or 
information from electronic frameworks. There are various proportions of promptness for incessant and non-regular administrations (a successive assistance is one which has at least 6 buses for every hour).

\section{Accessibility Index}

There are various valid justifications for improving the accessibility of transportation. Its improvement creates business by satisfying travelers. It assures extensive gathering of travelers consistently of the day and week. it brings comfort to people with disabilities, old aged people, parents with small children, tourists and ladies. Open urban communities will improve their notoriety among their residents, sightseers and guests by being known as comprehensive urban communities or areas. Improving accessibility will pull in travelers who might not already have thought about utilizing open vehicle. This will improve both the supportability and the adequacy of the urban vehicle framework (Øvstedal et al., 2011) [14].

\section{Calculating Total Access Time}

Total access time is comprised of a blend of variables: consolidating the walk time from the POI (Point-of-Interest - the point for which the PTAL (Public Transport Accessibility Levels) is being determined. This can be an individual point or a lattice of highlight) the SAP (Service Access Point transport stops, light rail stations, underground stations, tram link ends and so forth. Focuses at which individuals approach the open vehicle organize) and the time spent trusting that the ideal help will show up.

\section{Total Access Time $=$ Walk Time + Average Waiting Time}

Average Waiting Time: Waiting time is the average time between when a traveler shows up at a stop or station, and the appearance of the required assistance.

In PTALs travelers are accepted to show up at the SAP indiscriminately. For each chose segment of street, the scheduled waiting Time (SWT) is determined. This is assessed as a large portion of the progress (for example the span between administrations,) so SWT $=0.5 *$ (60/Frequency). Subsequently, a 10-minute assistance recurrence (6 transports for every hour) would give a SWT of 5 - on normal a traveler would need to sit tight 5 minutes for a transport/train to show up. To infer the Average Waiting Time, dependability factors are applied to the SWT as indicated by the method of transport utilized. The normality of transports, underground and rail administrations are influenced by an assortment of variables, with transport benefits the most exceedingly terrible influenced. To take into consideration dependability extra hold up times accepted that are 2 minutes for transports and 0.75 minutes for rail administrations.

\section{COMPUTING EQUIVALENT DOORSTEP FREQUENCY :}

The access time is converted to an Equivalent Doorstep Frequency (EDF) where:

\section{$\mathrm{EDF}=30 /$ Total Access Time (minutes)}

This treats access time as a notional Average Waiting Time like the segment of street was accessible at the "doorstep" of the chose POI.

\section{Ascertaining the Accessibility Index for the POI}

Summation of the EDF esteems gives the availability list. There are some of extra factors that ought to be thought of:

Section of roads frequently travels in equal for some separation so the range and recurrence of objections are probably going to be not as much as that recommended by the quantity of area of streets remembered for the computation.

Travelers regularly need to change section of roads so as to arrive at the destination - this can add noteworthy deferrals to the excursion dividing the EDF esteems for everything except the most open or prevailing section of road for each transport mode makes up for these components. Transport modes are separated into three gatherings:

Buses

Public Rail 
LUL - all LUL benefits along with DLR and Tramlink benefits Thus for a solitary vehicle mode the AIs can be determined using formula: Accessibility index $(\mathbf{A I})$ mode $=\mathbf{E D F m a x}+(\mathbf{0 . 5} *$ All other EDFs)

Calculating the overall accessibility index is a sum of the individual AIs over all modes:

Accessibility index $($ AI) poi $=\boldsymbol{\Sigma}($ AImode1 + AImode2 + AImode3 $+\ldots+$ AImode $n)$ (Anon., 2010)

- Average Network Speed

Average network speed must be computed as weighted average by the volume of service provided on different lines (Vuchic, 2005) [15].

Average network speed $\left(\overrightarrow{\left.\mathrm{V}_{\mathrm{ab}}\right)}=\frac{\sum_{\mathrm{i}} \mathrm{W}_{\mathrm{i}} \mathrm{V}_{\mathrm{i}}}{\sum_{\mathrm{i}} \mathrm{W}_{\mathrm{i}}}\right.$

Where,

$\mathrm{W}_{\mathrm{i}}=$ Wheightage

$\mathrm{V}_{\mathrm{i}}=$ Volume

- Walking time

Walking time is the time travelers need to sit tight at transport stops for transports. Longer holding up times show poor service. In developing nations to accomplish a sensible operation, the normal holding up time ought to be in the scope of 5 to 10 minute, with greatest holding up season of 10 to 20 minute under the predominant conditions (Wright et al. 1987) [9].

- Walking distance to bus stops

Walking distance to bus stops is the traveler needs to stroll to and from bus stops. It is a pointer of the inclusion. For dense urban area, it ought to be in the scope of 300 to $500 \mathrm{~m}$ from home to work place. Separation in abundance of $500 \mathrm{~m}$ might be adequate in low-dense area yet the greatest ought not to be surpassing $1000 \mathrm{~m}$ (Wright et al. 1987) [9].

\section{- Vehicle-km}

The work done by vehicles is given by vehicle-km. Vehicle-kilometers are the all-out separation went by bus in operation. A vehicle ought to be utilized a s seriously as could be expected under the circumstances, if adequate traffic is accessible to take care of the immediate expense of activity. A traveler conveyed per vehicle every day figures shows concentrated use through it doesn't demonstrate the practicality of the kilometers worked. Kilometers per vehicle are affected by working velocities; extent of inert to working time, long stretches of activity in day. Urban transports on throughout the day operation will ordinarily work somewhere in the range of 150 and 300 kilometers for each day. For a sensibly run transport administration the normal ought to be in the scope of 210160 (Wright et al. 1987) [9].

- Passenger Carried per Vehicle per day (PPVPD)

Traveler conveyed per vehicle every day is figured as all out travelers conveyed by absolute number of vehicles, and afterward isolated by the quantity of days in the period. It is a pointer of the degree of support of a vehicle operation. It is impacted by the vehicle limit, length of working day, length of road section, average distance traveled per traveler, demand with variation in peak and off peak and the kilometers worked per transport every day. Accepting $85 \%$ armada is operational, the typical range for a transport with a limit of 80-100 travelers on city administrations is somewhere in the range of 1000 and 2000 PPVPD. Addis Abab, 2500 traveler for each day, and Paris, 715 travelers for every day, are the over and underutilized limits (Wright et al. 1987) [9]. A sensibly all Single-deck bus should deliver 1000-1200Passenger per bus per day with crush capacity 80 (Wright et al. 1987) [9].

\section{- Passenger-km}

Work performed or "creation" of travel framework is communicated by passenger- km moved. It is processed when the traveler volume is increased by normal excursion length. 
The traveler volume can be taken from either the greatest burden area or normal volume along the line.

The travelers going during a predetermined period, typically 60 minutes, past a fixed point one way expecting boarding and landing just at travel stops or stations can be registered as: (Vuchic, 2005) [15].

Where,

$$
\text { Passenger volume }=B-A=\sum_{i}^{k} a_{i}-\sum_{i}^{k} b_{i}
$$

$\mathrm{a}_{\mathrm{i}}=$ alighting at any station $\mathrm{I}, \mathrm{i}=1 \ldots \mathrm{k}$

$\mathrm{bi}=$ boarding at any station $\mathrm{I}, \mathrm{i}=1 \ldots . \mathrm{k}$

$\mathrm{A}_{\mathrm{i}}=$ Cumulative alighting a line

$\mathrm{B}_{\mathrm{i}}=$ Cumulative boarding along a line

- Vehicle Operating Cost per km

It is characterized as the ratio of total operating cost to total distance travelled by vehicle. This can be expressed as,

\section{- Benefits (Revenue)}

$$
\text { Operating Cost per } \mathrm{km}=\frac{\text { Total operating cost }}{\text { Total distance travelled }}
$$

Significant income of transport operation is fare. Income is the measure of cash gathered from operation. At the point when contrast the income with expense and discover use is higher than the income. This is essentially on the grounds that the vehicles were old and the expense of maintenance was high. This shows the expense of activity and upkeep is more prominent than the income gathered from appropriation and levy. The negative net income gathered by the venture shows that its operations are not beneficial. It is prescribed that the income to cost proportion to be between 1.05:1 to 1.08:1 for the framework to operate effectively (Wright et al. 1987) [9].

According to De Jong et al., (2002) shows that for longer distance clinics, patients increasingly use public transport over walking in Dar Es Salaam. public vehicle in most of the nations is run under sponsorships and low income. In financial terms, the efficiency is reflected as income earned under the given expenses. As an open assistance, the productivity is more identified with level of accomplishing the targets, improved versatility and value, than benefit boost.

\section{Revenue per vehicle-km (Finance efficiency of Operation)}

It refers to the amount of investment required and/or gained to/from produce unit system output as given in the formula,

\section{Safety Indicators of Operation}

$$
\text { Revenue per vehicle } \mathrm{km}=\frac{\text { Total revenue }}{\text { total distance travelled }}
$$

Road safety indicators that have the capability of being globally equivalent One pointer that is possibly appropriate for universal correlations is the extent of mishaps happening at high danger destinations contrasted with all mishaps; yet it would require concurrence on the specific meaning of high danger locales. The lower the extent of high-hazard site mishaps, the better the wellbeing execution. Some Member States, for example Germany, the Netherlands and the UK, have created strategies for the investigation of road geometry or geological regions (for example urban or private) that present a higher mishap hazard territorial street wellbeing strategy. The danger is determined from number of fatalities (or mishaps) and presentation. This pointer surmises presentation information (kilometers driven, traffic volume). Street length could be considered rather than introduction, since presentation will much of the time not be accessible. The littler the contrast between streets in a class, the more homogeneous and safer is the street organize. Another wellbeing execution pointer that can be utilized for correlation between nations, is the distinction in hazard between the least sheltered and the 'signify' street in every classification. In the Netherlands, a comparable strategy is being created to help. Based on the description above analysis of satisfaction with the performance of urban public transport is very important to do research, to know the strengths 
and weaknesses of public transport services. The analysis of performance satisfaction of public transport is expected to provide a strategy to improve the performance of transit oriented towards satisfaction of urban public transport users. The proper gathering of data on road safety indicators at the most detailed level possible and encourage local authorities to use such data for local analysis and road safety planning (Brussels, 2001) [16].

\section{People Perception Indicators}

It is recommend developing people perception indicators to make them better applicable for decision making on investments in public transport. The existing and criticized indicators may be needed to make proper calculations for the type of indicator increase awareness. What is needed is a straightforward method to calculate scores on people centered indicators based on feasible data collection.

A quality function of transportation should be perceived by its users. The comfort, safety, security, friendliness, behavior of operator, etc determine the business value of transportation which need to be expressed in measurable form is difficult task. The transport operation should fulfill public expectation. The result of the visitor satisfaction provides useful information for sustainable urban public transport (Yaakub et al, 2011) [17].

\section{METHODOLOGY :}

\section{Research Conceptualization}

The research is a non-experimental quantitative and descriptive. The Flow chart of the research methodology is given in figure 2 .

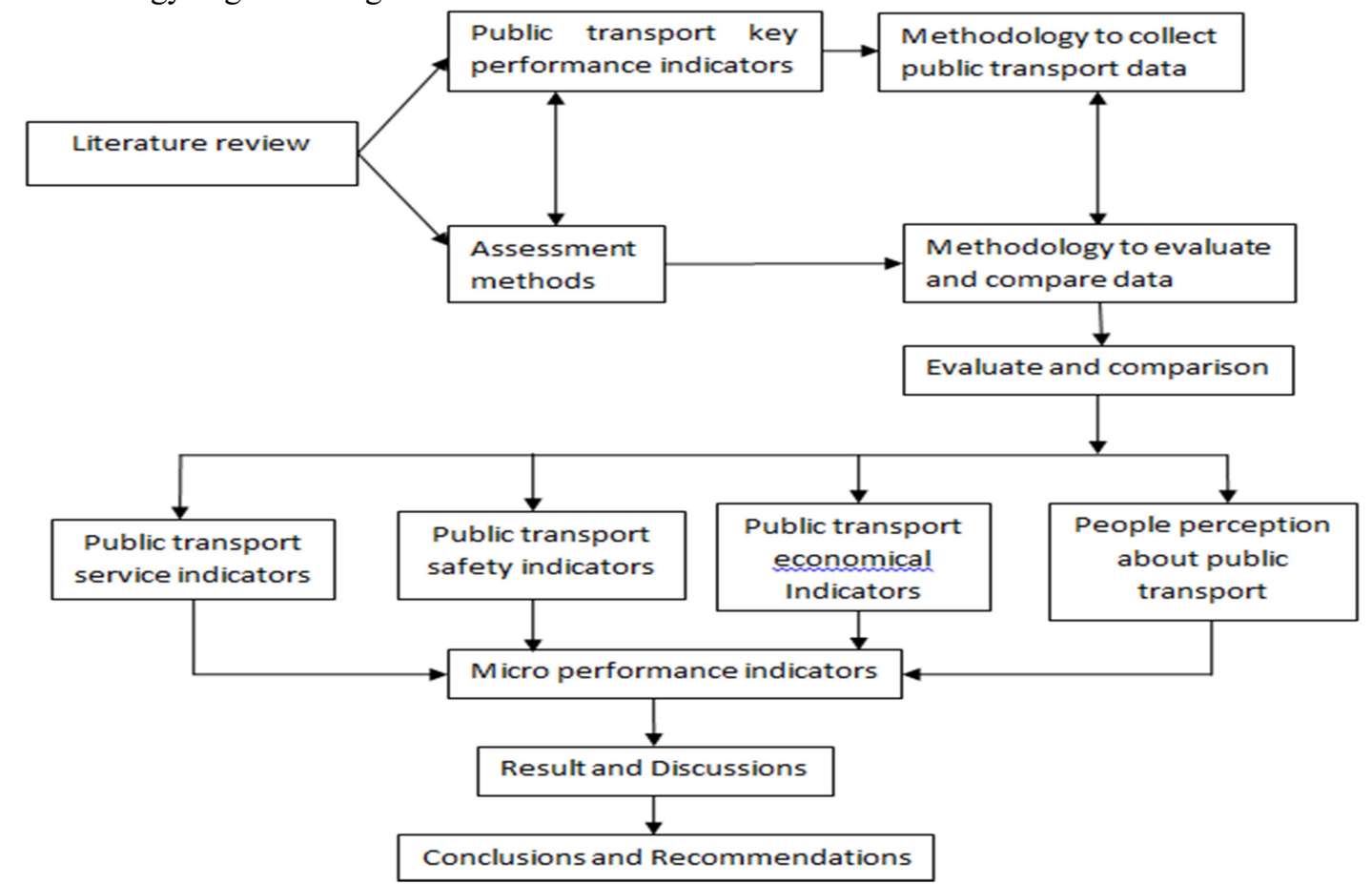

Fig. 2: Framework of the research methodology

In this study, Primary data from the SajhaYatayat, ThankotYatayat and SanyuktaYatayat are collected and that is supplemented by field observation. Later on, it is analyzed and interpreted the significance of findings to provide conclusions and recommendations.

\section{STUDY AREA :}

The research study area is Kathmandu district. Kalanki-Kalimati-Tripureshwor-Bhotahity section of road and back same way is the study section of road. It is one of the most important routes of the Kathmandu. The study section of road is shown in figure 3 bold black color line. There are 9 bus stops in study section of road. There are approximately 350-500 public vehicle ply at Tripureshwor Teku section of road during morning peak hour. Mostly three types of vehicle are operating in this 
section of road as freight, public transport \& private vehicle. Freight vehicle includes van, pickup, mini truck etc. Public transport includes bus, minibus, microbus etc. Private vehicle includes bike $\&$ car.

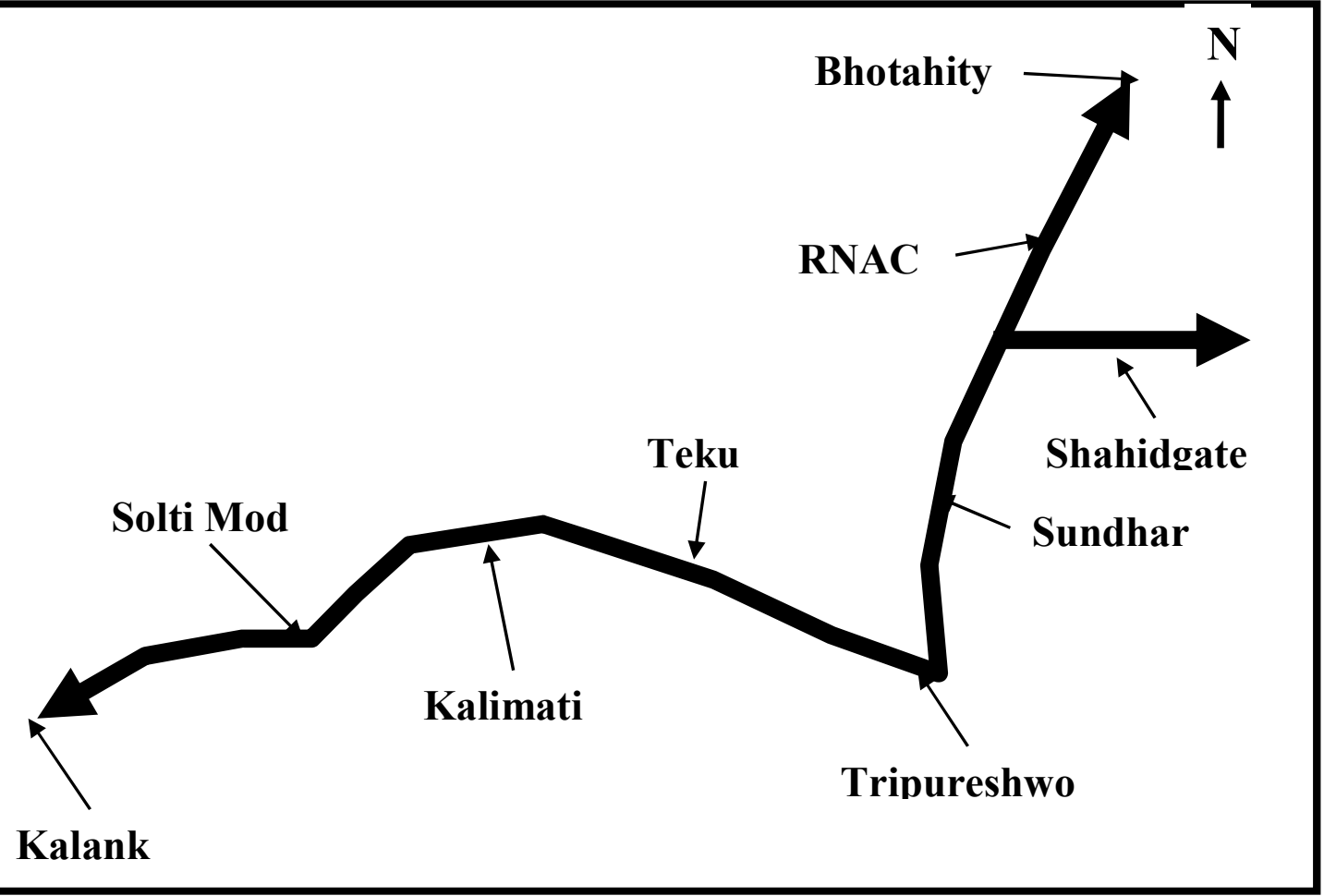

Fig.1: Operational Study section of road (Source: Modified from SajhaYatayat, 2011) [2]

\section{Study Population}

Here only consider SajhaYatayat, bus and microbus in this research though there is available some other public transport because other vehicle cannot compete to cope the recent traffic problem. We find 6SajhaYatayat, 100 buses and 97 microbuses under operation.

\section{Sample Selection}

\section{Sample Size}

To calculate the sample size Corchan equation (1963) with 95\% confidence level and precision of $10 \%$ is adopted. In sampling method, the entire samples are selected to conduct study from peak hour only as 09:00-11:00 am and 04:00-06:00 pm.

$$
\begin{gathered}
\mathrm{n}_{\mathrm{o}}=\frac{\mathrm{z}^{2} \mathrm{pq}}{\mathrm{e}^{2}} \\
\mathrm{n}=\frac{\mathrm{n}_{\mathrm{o}}}{1+\frac{\mathrm{n}_{\mathrm{o}}-1}{\mathrm{~N}}} \quad \text { (For finite sample) }
\end{gathered}
$$

Where,

$\mathrm{n}=$ Size of infinite population

$z=$ Area of normal curve with value 1.96 for $95 \%$ confidence level.

$\mathrm{p}=$ Estimated proportion of an attribute that is present in the population.

$\mathrm{q}=1-\mathrm{p}$

$\mathrm{N}=$ population size of public transport

$\mathrm{e}=$ the acceptable sampling error

Table 2: Sample size of SajhaYatayat, Bus, microbus and people for people perception 


\begin{tabular}{||c|l|c|c|c|c||}
\hline \hline S.N. & Selected public transport & $\begin{array}{c}\text { Public } \\
\text { transport no. }\end{array}$ & $\begin{array}{c}\text { Vehicle } \\
\text { Sample size }\end{array}$ & $\begin{array}{c}\text { People } \\
\text { Perception } \\
\text { population }\end{array}$ & $\begin{array}{c}\text { People } \\
\text { Perception } \\
\text { Sample }\end{array}$ \\
\hline \hline 1 & Total Study population & 203 & 67 & 3630 & \multirow{2}{*}{9} \\
\cline { 1 - 4 } 2 & SajhaYatayat & 6 & 2 & 200 & \\
\cline { 1 - 4 } 3 & Bus & 100 & 33 & 2310 & \\
\cline { 1 - 4 } 4 & Microbus & 97 & 32 & 1120 & \\
\hline
\end{tabular}

\section{DATA COLLECTION AND ANALYSIS :}

Eight enumerators were invited to collect traffic related data. Traffic related data were collected by number plate method with the help of enumerators. Each enumerator collected relevant data within given format on both sides each bus stops. Travel time by car measured by hiring a taxi.

\section{Indicators to compare the Selected Modes of Public Transport}

The total 87 operational indicators related to the public transport were collected and categorized based on analytical and questionnaire research. Most of the operational indicators are similar but expressed in different way. Performance indicators are shortlisted in such a way that represents number of similar indicators in one indicator. Total 38 shortlisted performance indicators are tabulated. Expert consultation was done in order to select the appropriate performance indicator based on data availability, costs to data collection, data quality and necessity. All experts are belonging to DoR. Total 29 performance indicators, got more than 40 percent mean score value, were selected and tabulated as revenue per $\mathrm{Km}$, cost per $\mathrm{Km}$, rate of return, running \& journey time, running \& journey speed, travel time ratio, running index, passenger waiting index, affordability index, bus punctuality, accessibility index, horn, lighting, first aid, driver Training, stopping bus at correct place, seat comfort ability, space availability, conductor behavior, female friendly, old friendly, child friendly, disable friendly, late hour service, recreation and traffic rule violation for this research

\section{RESULTS AND DISCUSSION :}

\section{Operational Performance of Public Transport}

The study is confined for peak hours only.

\section{Economical Indicators}

Table 3: Result of Economic Indicators

\begin{tabular}{|c|l|l|l|l|}
\hline \multirow{2}{*}{ S.N. } & \multirow{2}{*}{ Economical Indicators } & \multicolumn{3}{c|}{ Public vehicle } \\
\cline { 3 - 5 } & & \multicolumn{1}{|c|}{ SajhaYatayat } & \multicolumn{1}{c|}{ Bus } & \multicolumn{1}{c|}{ Microbus } \\
\hline 1 & Revenue per km (NRs) & 73.69 & 104.94 & 93.337 \\
\hline 2 & Cost per km (NRs) & 62.38 & 79.0123 & 67.4 \\
\hline 3 & Benefit cost(B/C) ratio & 1.181 & 1.328 & 1.35 \\
\hline 4 & Internal rate of return (\%) & 16.424 & 27.037 & 28.55 \\
\hline
\end{tabular}

The revenue per km of SajhaYatayat has less than other two while bus has highest. The cost per km of SajhaYatayat, bus and microbus has lowest, highest and mid value respectively. Microbus and SajhaYatayat has highest and lowest benefit cost ratio. B/C ratio of operational transports is greater than one indicating economic feasibility of operation without any subsidies. As suggested by Wright et al., it needs subsidies only when ranges below $1.05: 1$ to $1.08: 1 \mathrm{~b} / \mathrm{c}$ ratio. The internal rate of return of SajhaYatayat, Bus and microbus has lowest, mid and highest value respectively. It reveals that the selected public transports are performing better economically because IIR of all selected public transports are greater than interest rate $16 \%$ while most of the banks are proving automobile loan at below $10 \%$. Most of the United States and much of the world, public transport is publicly subsidized (Levinson, 2013) [1]. 


\subsection{Service Indicators of Operation}

\section{Running Time}

Running Time while traveling from Kalanki to Bhotahity

Running time was calculated from field survey by using number plate method when running from Kalanki to Bhotahity through mid busstops was tabulated in table 5 below.

Table 4: Running time while traveling from Kalanki to Bhotahity

\begin{tabular}{|c|l|l|l|l|}
\hline \multirow{2}{*}{$\begin{array}{c}\text { S. Section } \\
\text { N. }\end{array}$} & & \multicolumn{3}{c|}{ Running time (Sec.) } \\
\cline { 3 - 5 } & & SajhaYatayat & \multicolumn{1}{c|}{ Bus } & \multicolumn{1}{c|}{ Microbus } \\
\hline 1 & Kalanki-Solti Mod & 321 & 310.41 & 318.56 \\
\hline 2 & Solti Mod-Kalimati & 456 & 429.59 & 450.94 \\
\hline 3 & Kalimati-Teku & 336 & 332.12 & 327.6 \\
\hline 4 & Teku-Tripureshwor & 79 & 80.18 & 81.56 \\
\hline 5 & Tripureshwor-Sundhara & 101 & 100.18 & 100.6 \\
\hline 6 & Sundhara-RNAC & 83 & 85.59 & 80.44 \\
\hline
\end{tabular}

The observation of running time of public transport in the study section of road while running from Kalanki to Bhotahity shows that SajhaYatayat takes highest running time and bus have lowest running time. This shows that bus is running in higher speed.

Similarly, for Running Time Traveling from Shahidgate to Kalanki

Running time was calculated from field survey by using number plate method when running from Shahidgate to Kalanki through mid busstops was tabulated in table 6 below. The observation of running time of public transport in the study section of road while running from Shahidgate to Kalanki shows that highest running time was taken by bus and lowest running time was taken by Microbus. This indicates that microbus is running at higher speed than other.

Table 5: Running Time Traveling from Shahidgate to Kalanki

\begin{tabular}{|c|l|l|l|l|}
\hline \multirow{2}{*}{$\begin{array}{c}\text { S. } \\
\text { N. }\end{array}$} & \multicolumn{1}{|c|}{ Section } & \multicolumn{3}{c|}{ Running time (Sec.) } \\
\cline { 3 - 5 } & & \multicolumn{1}{c|}{ Sajha Yatayat } & \multicolumn{1}{c|}{ Mus } \\
\hline 1 & Shahidgate - Tripureshwor & 108 & 110.25 & 103.56 \\
\hline 2 & Tripureshwor - Teku & 105 & 106.5 & 103.06 \\
\hline 3 & Teku - Kalimati & 354 & 347.8 & 352.94 \\
\hline 4 & Kalimati - Solti Mod & 473 & 474 & 466.38 \\
\hline 5 & Solti Mod - Kalanki & 230 & 242 & 237 \\
\hline \multicolumn{2}{r|r}{ Total } & 1270 & 1280.55 & 1262.94 \\
\hline
\end{tabular}

There is no different bus lane in the route, so it needs to vie for space with other traffic in the occupied and restricted street arrange. The separation between the stops is longer which makes the movement time huge and the framework is more adaptable. It requires some investment in stacking and emptying traveler at transport stops. Because of clogged traffic at one hand and terrible showing of the administrators then again, the progress is long henceforth individuals stand by longer at transport stops.

Journey Time

Journey Time while running from Kalanki to Bhotahity

Journey time was calculated from field survey by using number plate method when running from Kalanki to Bhotahity through mid-bus stops was tabulated in table 6 below. The journey time of operation from Kalanki to Bhotahity shows that the bus runs at higher speed.

Table 6: Journey Time while running from Kalanki to Bhotahity

\begin{tabular}{|c|c|c|c|c|c|c|c|c|c|c|}
\hline \multirow{2}{*}{$\begin{array}{l}\mathbf{S} . \\
\mathbf{N}\end{array}$} & \multirow[b]{2}{*}{ Section } & \multicolumn{3}{|c|}{ Running time (Sec.) } & \multicolumn{3}{|c|}{ Wait (Sec.) } & \multicolumn{3}{|c|}{ Journey time (Sec.) } \\
\hline & & $\mathbf{S}$ & B & $\mathbf{M}$ & $\mathbf{S}$ & B & M & S & B & M \\
\hline 1 & $\begin{array}{l}\text { Kalanki-Solti } \\
\text { Mod }\end{array}$ & 321 & 310.41 & 318.56 & 9 & 7.88 & 10.13 & 330 & 318.29 & 328.69 \\
\hline 2 & Mod- & 456 & 429.59 & 450.94 & 12 & 9.53 & 11.19 & 468 & 439.12 & 462.13 \\
\hline
\end{tabular}

Anjay Kumar Mishra, et al, (2020); www.srinivaspublication.com 
International Journal of Case Studies in Business, IT, and Education (IJCSBE), ISSN: 2581-6942, Vol. 4, No. 2, September 2020.

\begin{tabular}{|c|l|l|l|l|l|l|l|l|l|l|}
\hline & Kalimati & & & & & & & & & \\
\hline 3 & $\begin{array}{l}\text { Kalimati- } \\
\text { Teku }\end{array}$ & 336 & 332.12 & 327.6 & 8 & 9.82 & 10.50 & 344 & 341.94 & 338.13 \\
\hline 4 & $\begin{array}{l}\text { Teku- } \\
\text { Tripureshwor }\end{array}$ & 79 & 80.18 & 81.56 & 10 & 10.18 & 10.50 & 89 & 90.35 & 92.06 \\
\hline 5 & $\begin{array}{l}\text { Tripureshwor } \\
\text {-Shahidgate }\end{array}$ & 101 & 100.18 & 100.6 & 6 & 8.88 & 10.19 & 107 & 109.06 & 110.75 \\
\hline 6 & $\begin{array}{l}\text { Shahidgate- } \\
\text { RNAC }\end{array}$ & 83 & 85.59 & 8.44 & 46 & 26.53 & 22.81 & 129 & 112.12 & 103.25 \\
\hline 7 & $\begin{array}{l}\text { RNAC- } \\
\text { Bhotahity }\end{array}$ & 49 & 50.41 & 47.9 & 8 & 7.94 & 9.94 & 57 & 58.35 & 57.88 \\
\hline Total & $\begin{array}{l}142 \\
5\end{array}$ & $\begin{array}{l}1388.4 \\
8\end{array}$ & 1407.6 & 99 & 80.76 & 85.26 & $\begin{array}{l}152 \\
4\end{array}$ & $\begin{array}{l}1469.2 \\
4\end{array}$ & $\begin{array}{l}1555.8 \\
6\end{array}$ \\
\hline
\end{tabular}

Note: S-SajhaYatayat, B-Bus \& M-Microbus

\section{Journey Time while running from Shahidgate to Kalanki}

Journey time was calculated from field survey by using number plate method when running from Shahidgate to Kalanki through mid busstops was tabulated in table 7 below.

Table 7 : Journey Time while running from Shahidgate to Kalanki

\begin{tabular}{|c|c|c|c|c|c|c|c|c|c|c|}
\hline \multirow{2}{*}{$\begin{array}{l}\mathbf{S} . \\
\mathbf{N}\end{array}$} & \multirow[t]{2}{*}{ Section } & \multicolumn{3}{|c|}{ Running time (Sec.) } & \multicolumn{3}{|c|}{ Wait (Sec.) } & \multicolumn{3}{|c|}{ Journey time (Sec.) } \\
\hline & & $\mathbf{S}$ & B & $\mathbf{M}$ & $\mathbf{S}$ & B & M & $\mathbf{S}$ & B & $\mathbf{M}$ \\
\hline 1 & $\begin{array}{l}\text { Shahidgate - } \\
\text { Tripureshwor }\end{array}$ & 108 & 110.25 & 103.56 & 12 & 10 & 10.69 & 120 & 120.25 & 114.25 \\
\hline 2 & $\begin{array}{l}\text { Tripureshwor } \\
\text { - Teku }\end{array}$ & 105 & 106.5 & 103.06 & 15 & 14.63 & 11.38 & 120 & 121.13 & 114.44 \\
\hline 3 & $\begin{array}{l}\text { Teku } \\
\text { Kalimati }\end{array}$ & 354 & 347.8 & 352.94 & 11 & 10.68 & 9.94 & 365 & 358.5 & 362.88 \\
\hline 4 & $\begin{array}{ll}\text { Kalimati } & - \\
\text { Solti Mod } & \\
\end{array}$ & 473 & 474 & 466.38 & 10 & 12.19 & 12.88 & 483 & 486.19 & 479.25 \\
\hline 5 & $\begin{array}{l}\text { Solti Mod - } \\
\text { Kalanki }\end{array}$ & 230 & 242 & 237 & 9 & 10.44 & 10.13 & 239 & 252.44 & 247.13 \\
\hline & Total & $\begin{array}{l}127 \\
0\end{array}$ & $\begin{array}{l}1280.5 \\
5\end{array}$ & $\begin{array}{l}1262.9 \\
4 \\
\end{array}$ & 57 & 57.94 & 55.02 & $\begin{array}{l}132 \\
7 \\
\end{array}$ & 1338.5 & $\begin{array}{l}1317.9 \\
6 \\
\end{array}$ \\
\hline
\end{tabular}

The observation of journey time of public transport in the study section of road while running from Shahidgate to Kalanki shows that highest journey time was taken by bus and lowest running time was taken by Microbus. It indicates microbus runs at higher speed.

It ought not to be more than $2 / 3$ hours out of each day. Unreasonable excursion time reflects weak operation (Wright et al.1987) [9].

\section{Running Speed}

Running speed was calculated while running from Kalanki to Bhotahity using the ratio of distance to time, where distance was used as secondary source (SajhaYatayat) and running time was measured from field survey by using number plate method when running from Kalanki to Bhotahity through mid busstops was tabulated in table 8 below.

Table 8 : Running Speed while running from Kalanki to Bhotahity

\begin{tabular}{|c|l|l|l|c|c|c|c|c|}
\hline S. & \multicolumn{1}{|c|}{ Section } & Distance & \multicolumn{3}{|c|}{ Running time (Sec.) } & \multicolumn{3}{|c|}{ Running speed (m/s) } \\
\cline { 5 - 9 } N & & $(\mathbf{m})$ & $\mathbf{S}$ & $\mathbf{B}$ & $\mathbf{M}$ & $\mathbf{S}$ & $\mathbf{B}$ & $\mathbf{M}$ \\
\hline $\mathbf{1}$ & & & & & & & & \\
\hline & $\begin{array}{l}\text { Kalanki-Solti } \\
\text { Mod }\end{array}$ & 2900 & 321 & 310.41 & 318.56 & 9.034 & 9.34 & 9.103 \\
\hline 2 & Solti Mod- & 900 & 456 & 429.59 & 450.94 & 1.974 & 2.09 & 1.996 \\
\hline
\end{tabular}

Anjay Kumar Mishra, et al, (2020); www.srinivaspublication.com 
International Journal of Case Studies in Business, IT, and Education (IJCSBE), ISSN: 2581-6942, Vol. 4, No. 2, September 2020.

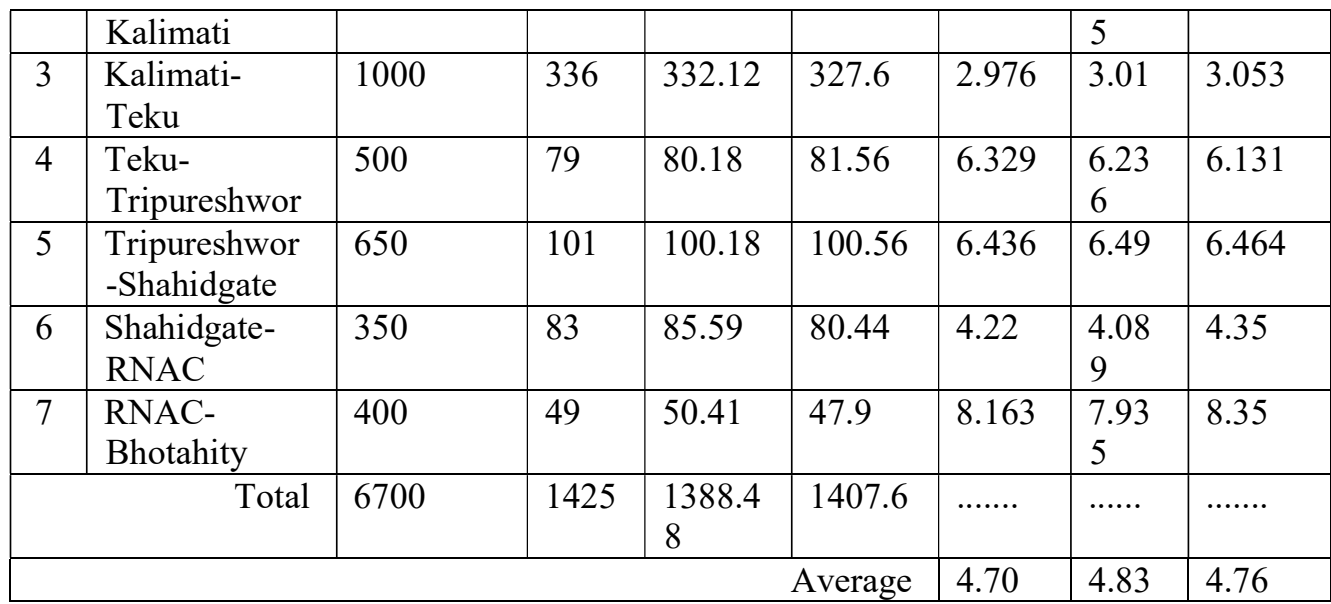

The observation of running speed of public transport in the study section of road while running from Kalanki to Bhotahity shows that bus runs at highest running speed as $17.39 \mathrm{kph}$, SajhaYatayat runs at lowest running speed as $16.92 \mathrm{kph}$. Nepal (2005) obtained average speed $15.77 \mathrm{kph}$ for bus \& minibus and $23.87 \mathrm{kph}$ for microbus in RNAC to Ratnapark section of road.

Similarly, Running speed from Shahidgate to Kalanki through mid busstops was observed.

The observation of running time of public transport in the study section of road while running from Shahidgate to Kalanki shows that Microbus runs at highest running speed as $17.68 \mathrm{kph}$, Bus runs at lowest running speed as $17.42 \mathrm{kph}$. Nepal (2005) had obtained average speed $15.77 \mathrm{kph}$ for bus \& minibus and $23.87 \mathrm{kph}$ for microbus in RNAC to Ratnapark section of road at 2005 AD.

Journey Speed

Journey Speed while running from Kalanki to Bhotahity

Journey speed was calculated from ratio of distance to time, where distance was used as secondary source (SajhaYatayat) and Journey time was measured from field survey by using number plate method when running from Kalanki to Bhotahity through mid bus stops was tabulated in table 9 below.

Table 9: Journey Speed while running from Kalanki to Bhotahity

\begin{tabular}{|c|c|c|c|c|c|c|c|c|}
\hline \multirow{2}{*}{$\begin{array}{l}\mathbf{S} . \\
\mathbf{N}\end{array}$} & \multirow[t]{2}{*}{ Section } & \multirow{2}{*}{$\begin{array}{l}\text { Distance } \\
\text { (m) }\end{array}$} & \multicolumn{3}{|c|}{ Journey time (Sec.) } & \multicolumn{3}{|c|}{ Journey speed $(\mathrm{m} / \mathrm{s})$} \\
\hline & & & $\mathbf{S}$ & B & M & $\mathbf{S}$ & B & $\mathbf{M}$ \\
\hline 1 & $\begin{array}{l}\text { Kalanki-Solti } \\
\text { Mod }\end{array}$ & 2900 & 330 & 318.29 & 328.69 & 8.79 & 9.11 & 8.82 \\
\hline 2 & $\begin{array}{l}\text { Solti Mod- } \\
\text { Kalimati }\end{array}$ & 900 & 468 & 439.12 & 462.13 & 1.92 & 2.05 & 1.95 \\
\hline 3 & $\begin{array}{l}\text { Kalimati- } \\
\text { Teku }\end{array}$ & 1000 & 344 & 341.94 & 338.13 & 2.91 & 2.92 & 2.96 \\
\hline 4 & $\begin{array}{l}\text { Teku- } \\
\text { Tripureshwor }\end{array}$ & 500 & 89 & 90.35 & 92.06 & 5.62 & 5.53 & 5.43 \\
\hline 5 & $\begin{array}{l}\text { Tripureshwor } \\
\text {-Sundhara }\end{array}$ & 650 & 107 & 109.06 & 110.75 & 6.07 & 5.96 & 5.87 \\
\hline 6 & $\begin{array}{l}\text { Sundhara- } \\
\text { RNAC }\end{array}$ & 350 & 129 & 112.12 & 103.25 & 2.71 & 3.12 & 3.39 \\
\hline 7 & $\begin{array}{l}\text { RNAC- } \\
\text { Bhotahity }\end{array}$ & 400 & 57 & 58.35 & 57.88 & 7.02 & 6.85 & 6.91 \\
\hline & Total & 6700 & 1524 & 1469.24 & 1555.86 & $\ldots . . .$. & ....... & ........ \\
\hline & & & & & Average & 4.40 & 4.56 & 4.31 \\
\hline
\end{tabular}

The observation of journey speed of public transport in the study section of road while running from Kalanki to Bhotahity shows that bus runs at highest running speed as $16.42 \mathrm{kph}$, microbus runs at 
lowest journey speed as $15.48 \mathrm{kph}$. Nepal (2005) had obtained average speed $15.77 \mathrm{kph}$ for bus \& minibus and $23.87 \mathrm{kph}$ for microbus in RNAC to Ratnpark section.

Similarly, for Journey Speed while running from Shahidgate to Kalanki

Journey speed was calculated from ratio of distance to time, where distance was used as secondary source (SajhaYatayat) and journey time was measured from field survey by using number plate method when running from Shahidgate to Kalanki through mid bus stops was done.

The observation of running time of public transport in the study section of road while running from Shahidgate to Kalanki shows that Microbus runs at highest journey speed as $16.96 \mathrm{kph}$, Bus runs at lowest journey speed as $16.67 \mathrm{kph}$. Nepal (2005) had obtained average speed $15.77 \mathrm{kph}$ for bus \& minibus and $23.87 \mathrm{kph}$ for microbus in RNAC to Ratnapark section of road.

The benchmark for journey speed is usually $10 \mathrm{~km} / \mathrm{h}$ in dense urban area with mixed traffic and $25 \mathrm{~km} / \mathrm{h}$ in medium-low density areas. In dense areas in mixed traffic, this should be a minimum of 10-to-12 kph and in bus-only lanes, 15 -to-18 kph. In medium- to low-density areas, journey speeds of approximately $25 \mathrm{kph}$ should be expected.

While comparing the Running time of Kathmandu with that of benchmark of other country as shown in literature review section, it does not reflect any deficiency.

Travel Time Ratio

Travel Time Ratio while running from Kalanki to Bhotahity

Travel time by SajhaYatayat $\quad=1425 \mathrm{Sec}$

Travel time by bus $\quad=1388.84 \mathrm{Sec}$

Travel time by microbus $\quad=1407.6 \mathrm{Sec}$

Average Travel time by public transport $=(1424+1388.84+1407.6) / 3=1407.15 \mathrm{Sec}$

Travel time by car (bike) $\quad=859 \mathrm{Sec}$

Table 10 : Travel time ratio while running from Kalanki to Bhotahity

\begin{tabular}{|c|l|c|c|}
\hline S.N. & Public transport & $\begin{array}{c}\text { Travel time by public } \\
\text { transport ( Sec) }\end{array}$ & $\begin{array}{c}\text { Travel Time } \\
\text { Ratio }\end{array}$ \\
\hline 1 & SajhaYatayat & 1425 & 1.66 \\
\hline 2 & Bus & 1388.84 & 1.62 \\
\hline 3 & Microbus & 1407.6 & 1.64 \\
\hline \multicolumn{2}{r|}{ Average } & 1407.15 & 1.64 \\
\hline
\end{tabular}

From the analysis, it was found that travel time ratio while running from Kalanki to Bhotahity for Microbus was in between that of SajhaYatayat and bus as 1.64 but SajhaYatayat and bus have highest as 1.66 and lowest as 1.62 respectively. According to Kumar et al. (2013) [11], the travel time ratio fluctuates from 1 to 5 for most trips and generally the larger the ratio is less competitive. Therefore, all calculated values are between 1 and 5 so selected public vehicle performance are satisfactory. In precisely, bus is more competitive than others.

Similarly, Travel Time Ratio while running from Shahidgate to Kalanki

Travel time by SajhaYatayat $\quad=1270 \mathrm{Sec}$, Travel time by bus $\quad=1280.55 \mathrm{Sec}$

Travel time by microbus $=1262.94 \mathrm{Sec}$, Average Travel time by public transport= $(1270+1280.55+1262.94) / 3=1271.16 \mathrm{Sec}$ and Travel time by car $\quad=681 \mathrm{Sec}$

Travel time ratio while running from Shahidgate to Kalanki as: Travel time ratio of SajhaYatyat was in between that of bus and microbus as 1.86 while bus and microbus have highest as 1.88 and lowest as 1.85 respectively. According to Kumar et al. (2013) [11], the travel time ratio fluctuates from 1 to 5 for most trips and generally the larger the ratio is less competitive. Therefore, all calculated values are between 1 and 5 so selected public vehicle performance are satisfactory. In precisely, microbus is more competitive than others.

\section{Running Index}

According to transport services, they have no certain service time and schedule for transport service due to heavy frequent congestion and difficult to follow schedule. They claim that their target to run transport service at 20-30 kph. So, service time calculated by unity method as,

Time required to run $6700 \mathrm{~m}$ distance $=\frac{3600}{25} * 6.7=965 \mathrm{Sec}$ (Kalanki to Bhotahity section)

Anjay Kumar Mishra, et al, (2020); www.srinivaspublication.com 
Time required to run $6700 \mathrm{~m}$ distance $=\frac{3600}{25} * 6.2=893 \mathrm{Sec}$ (Shahidgate to Kalanki section)

Table 11: Running Index while running from Kalanki to Bhotahity

\begin{tabular}{|c|l|c|c|c|c|}
\hline S.N. & \multicolumn{1}{|c|}{ Public transport } & $\begin{array}{c}\text { Total service } \\
\text { time (Sec.) }\end{array}$ & $\begin{array}{c}\text { Total travel } \\
\text { time (Sec.) }\end{array}$ & $\begin{array}{c}\text { Running } \\
\text { index }\end{array}$ & Remarks \\
\hline 1 & SajhaYatayat & 965 & 1524 & 0.63 & \\
\hline 2 & Bus & 965 & 1469.24 & 0.68 & \\
\hline 3 & Microbus & 965 & 1492.88 & 0.65 & \\
\hline \multicolumn{2}{|r|}{ Average running index } & 0.65 & \\
\hline
\end{tabular}

From the analysis, it was found that running index while running from Kalanki to Bhotahity as: The running index of Microbus was in between that of SajhaYatayat and bus as 0.65 while SajhaYatayat and bus have lowest as 0.63 and highest as 0.68 respectively. The average running index selected public transport was 0.65 . According to Kumar et al. (2013) [11], running index should be between 0.15 and 0.75 for passengers' satisfaction. As RI value increases, efficiency of the system decreases. Therefore, all calculated value is between 0.15 and 0.75 indicating that performance of selected public transport is satisfactory. In precisely, SajhaYatayat is more competitive than others.

Similarly, from the Running Index while running from Shahidgate to Kalanki, it was found that running index while running from Shahidgate to Kalanki as: The running index of Microbus was highest as 0.74 while SajhaYatayat and bus has same values as 0.73 . The average running index of public transport was 0.73. According to Kumar et al. (2013) [11], running index should be between 0.15 and 0.75 for passengers' satisfaction. As RI value increases, efficiency of the system decreases. Therefore, all calculated value is between 0.15 and 0.75 indicating that performance of selected public transport is satisfactory. In precisely, SajhaYatayat and bus are more competitive than others.

\section{Passenger Waiting Index}

We have, from field survey

Mean passenger waiting time $=332.33 \mathrm{Sec}$

Frequency of transport service at Tripureshwor was 420 while travelling from Kalanki to Bhotahity and 340 while travelling from Shahidgate to Kalanki.

Frequency of transport service $=(420+340) / 2=380$

Passenger waiting index was expressed as,

$$
\text { Passenger Waiting Index }=\frac{\text { Mean passenger waiting time }}{\text { Frequency of transport service }}=\frac{332.33}{380}=0.88
$$

From the analysis of comparison with Kumar et. al (2013) [11], it was found that waiting index of public transport in study route is 0.88 which is between 0 and 1 reflecting optimum nearly recommended index 0.825 for public transport operation If the traveler holding to be embarked ought to be equal or less than the occupancy available in the vehicle. The passenger waiting result is more than 1 indicates that the frequency or number of public transports is lower than passenger demand. The obtained passenger waiting index is nearly equal to $0.88 \approx 1$ so selected public transport is performing in optimum condition during peak hour.

No one wants to wait though about 55\% need to stand by generally for 5-10 minutes day by day for transportation during morning peak hours. $19.3 \%$ generally sit tight for under 5 minutes, $17.5 \%$ generally for 10-15 minutes and 5.8\% need to stand by generally for $15-20$ minutes day by day during morning peak hours.

Affordability Index

Per capita income $=2400$ Dollar $=243672$ Nrs ( 1 US dollar $=101.53$ on 2072.03.14, Kantipur daily)

Table 12: Affordability Index

\begin{tabular}{|c|c|l|l|l|l|}
\hline $\begin{array}{c}\text { S. } \\
\text { N }\end{array}$ & $\begin{array}{c}\text { Public } \\
\text { transport }\end{array}$ & No. of trips & $\begin{array}{c}\text { Avg. cost } \\
\text { per trip }\end{array}$ & $\begin{array}{c}\text { Per capita } \\
\text { income }\end{array}$ & $\begin{array}{c}\text { Affordability } \\
\text { index }\end{array}$ \\
\hline 1 & SajhaYatayat & 6.5 & 1448 & 243672 & $3.86 \%$ \\
\hline
\end{tabular}

Anjay Kumar Mishra, et al, (2020); www.srinivaspublication.com 


\begin{tabular}{|l|l|l|l|l|l|}
\hline 2 & Bus & 5 & 1450 & 243672 & $2.98 \%$ \\
\hline 3 & Microbus & 8.5 & 1280 & 243672 & $4.47 \%$ \\
\hline \multicolumn{5}{|r|}{ Avg. } & $3.77 \%$ \\
\hline
\end{tabular}

From the analysis, it was found that affordability index of Microbus and Bus are highest as $4.47 \%$ and lowest as $2.98 \%$ respectively while SajhaYatayat has in between bus and microbus as $3.86 \%$. The mean average of affordability index of public transport was $3.77 \%$.

Public transport is for providing service not for profit. So, it should cover only owning and operating cost no more than that. AS suggested in literature, it should not be more than that of disposable income has been easily maintained here in Nepal.

\section{Bus Punctuality}

Table 13: Bus Punctuality

\begin{tabular}{|l|l|l|l|}
\hline S.N. & Public transport & \multicolumn{1}{|c|}{ No. of bus per hour } & \multicolumn{1}{|c|}{ Bus punctuality } \\
\hline 1 & SajhaYatayat & 2 & Non frequent \\
\hline 2 & Bus & 12 & Frequent \\
\hline 3 & Micro bus & 12 & Frequent \\
\hline
\end{tabular}

From the analysis, it was found that number of SajhaYatayat is 2 and 12 for bus and microbus per hour in the study section. According to Tranter 2013, frequent public transport service is one that has no less than 6 buses per hour. Therefore, SajhaYatayat is non-frequent and bus and microbus are frequent.

\section{Accessibility Index}

From the field observation, it was found that accessibility index is equal for all selected public transport in the study section because they share same bus stops.

Safety Indicators

Safety indicators that include as horn, lighting, first aid and driver training are tabulated in table 14 with the help of Likert scale.

Table 14 : Safety Indicators

\begin{tabular}{|c|l|c|c|c|}
\hline \multirow{2}{*}{ S.N. } & \multirow{2}{*}{ Safety Indicators } & \multicolumn{3}{|c|}{ Public vehicle } \\
\cline { 3 - 5 } & & SajhaYatayat & Bus & Microbus \\
\hline 1 & Horn & 5 & 4.484 & 5 \\
\hline 2 & Lighting & 5 & 5 & 5 \\
\hline 3 & First Aid & 5 & 3 & 1 \\
\hline 4 & Driver Training & 1 & No & No \\
\hline
\end{tabular}

From the analysis, it was found that Safety indicator of SajhaYatayat was well managed than bus and microbus. In detail, Horn of SajhaYatayat and microbus are well managed than bus while horn of few buses was not found in working condition. Lighting of all vehicles was in proper condition. First aid of SajhaYatayat was well managed than other two. First aid of microbus was found in worst condition while first aid of bus slightly better than Microbus.

The passenger's opinion on safety issues while travelling in different mode of transport showed that about $18.8 \%$ of passengers perceive microbus as unsafe, $12.9 \%$ perceive the same way for minibus and $15.2 \%$ perceive that buses are unsafe. while $52.4 \%$ of passenger perceive minibuses quite safe, $57.8 \%$ perceive buses as safe, $50.6 \%$ perceive microbus as safe while only 33.2 perceive 3 -wheelers can be safe (Udas, 2013) [18].

\section{People Perception of Public Transport Operations}

Total sample equally divided into 8 parts due to 8 numbers of bus stops and again divided equally due to two sides of bus stops. The number of people was selected as 11,12,12, 12, 12, 12, 6 and 6 at Kalanki, Solti Mod, Kalimati, Teku, Tripureshwor, Sundhara, RNAC and Bhotahity respectively but 11 people at Shahidgate due to one way at RNAC and Bhotahity. (Hint: Question as which public vehicle stops at correct place with option SajhaYatayat, bus and microbus. Where, Total 
population $=94,72$ people said SajhaYatayat, 10 people said bus, 4 people said microbus and 8 people said no any. Calculation for SajhaYatayat $=(72 / 94) * 100)=76.6$

Table 15: People Perception Indicators

\begin{tabular}{|c|l|c|c|c|c|}
\hline \multirow{2}{*}{$\begin{array}{l}\text { S. } \\
\text { N. }\end{array}$} & People perception Indicators & \multicolumn{4}{|c|}{ Public vehicle (\%) } \\
\cline { 3 - 6 } & & SajhaYatayat & Bus & Microbus & No any \\
\hline 1 & Vehicle staff behavior & 70.21 & 12.77 & 3.19 & 13.83 \\
\hline 2 & Stopping bus at correct place & 76.6 & 10.64 & 4.26 & 8.51 \\
\hline 3 & Seat comfort ability & 62.77 & 11.7 & 6.38 & 19.15 \\
\hline 4 & Space availability & 46.81 & 23.4 & 6.38 & 23.4 \\
\hline 5 & Female friendly & 39.36 & 44.68 & 12.77 & 3.19 \\
\hline 6 & Old friendly & 24.47 & 56.38 & 9.57 & 9.57 \\
\hline 7 & Child friendly & 11.7 & 6.38 & 5.32 & 75.53 \\
\hline 8 & Disable friendly & 18.09 & 9.57 & 4.26 & 68.09 \\
\hline 9 & Late hour service & 27.66 & 47.87 & 20.21 & 4.26 \\
\hline 10 & Well recreation & 41.26 & 26.6 & 25.53 & 6.38 \\
\hline 11 & Traffic rule violation & 3.19 & 27.66 & 67.02 & 2.13 \\
\hline \multicolumn{2}{|r|}{ Average } & 38.37 & 25.24 & 14.99 & 21.27 \\
\hline
\end{tabular}

(Hints: SajhaYatayat has $3.19 \%$, bus has $27.66 \%$, microbus has 67.02 and no any has $2.13 \%$ for traffic rule violation. Here $3.19 \%$ numerical value indicates that according to $3.19 \%$ of sample size of population $(94 \times 3.19 \%=3)$, SajhaYatayat violates the traffic rule so on.)

It was found that people perception indicators average values of SajhaYatayat, bus and microbus are $38.37 \%, 25.54 \%$ and $14.99 \%$ respectively. According to, $21.27 \%$ people, no any public transports are not well facilitated in order to cover the demand of all people in the study section of road. In comparison, SajhaYatayat has highest value of vehicle staff behavior, stopping bus at correct place, seat comfort ability, space availability, child friendly, disable friendly and well recreation are as $70.21 \%, 76.6 \%, 62.77 \%, 46.81 \%, 11.7 \%, 18.09 \%$ and $41.26 \%$ respectively. Bus has highest values of female friendly, old friendly and late hour service was as $44.68 \%, 56.38 \%$ and 47.875 respectively. Microbus has highest values of traffic rule violation was as $67.02 \%$. No any vehicle among three are not satisfied according to $75.53 \%$ and $68.09 \%$ people in case of child friendly and disable friendly respectively.

About $68.3 \%$ traveler thinks practices about some driver/conductors are neighborly and some are discourteous. $11.1 \%$ feel they are impolite, $10.7 \%$ feel they are lethargic while $3.4 \%$ feel driver/conductor being injurious and just $6.5 \%$ feel that they are obliging. As indicated by open vehicle, set of principles, drivers/conductors and travelers ought to be obliging towards one another and edified dialects ought to be utilized in broad daylight transport making condition benevolent towards ladies, kids and old. About $76 \%$ of travelers concurred that drivers to a great extent will in general adhere to rules on nearness of policemen just while $16.1 \%$ figure they don't keep traffic manages at all whenever. Different traffic rules are being penetrated by drivers on regular routine, for example, propensity of not observing path rule, propensity for sitting tight for travelers at effectively clogged intersections, picking and dropping traveler anyplace. As indicated by open discernment, $84.1 \%$ concur that drivers ought to follow traffic rules while getting and dropping travelers. Just $14.9 \%$ have different thoughts that this current pattern of getting and dropping any place is fine. In any case, actually check generally individuals will in general get into and drop out any place they like. As per open vehicle set of accepted rules, travelers ought to be picked and dropped securely in determined stops by open vehicle. At the point when travelers were approached on inclination for method of movement, $49.3 \%$ wanted to go in microbus, and $39.5 \%$ were agreeable to transport and minibus. Larger part of traveler appears to incline toward microbus, transport and minibus dependent on its high inhabitance structure, rebate for understudies in transport passage, comfort in seating space and speed (Udas, 2013) [18].

\section{CONCLUSIONS :}

Anjay Kumar Mishra, et al, (2020); www.srinivaspublication.com 
Economic analysis reveals that microbus have highest internal rate of return and benefit cost ratio highest while bus have highest revenue per kilometer and cost per kilometer SajhaYatayat has highest travel time ratio and running time, microbus has highest journey time, bus has highest running speed, journey speed and running index while traveling from Kalanki to Bhotahity respectively. Average passenger waiting index is 0.88 and this result is applicable for strategic development. Affordability index of microbus is $4.47 \%$ respectively. Bus punctuality of SajhaYatayat is non-frequent but bus and microbus are Frequent. Accessibility index of all public transport are equal for each bus stop due common (sharing) bus stops. Safety indicator of SajhaYatayat is well managed than bus and microbus.

It is known that more than a half of the passengers feel uncomfortable during peak hour while travelling due to overloaded vehicle, misconduct of staff, haphazard stoppage of vehicles and unscheduled vehicles. Lack of strong enforcement of traffic rules and regulation is one of the main causes for inappropriate public transport service.

The KPIs of public transport operation is best permanent point for indicators today to take as bench marks for SajhaYatayat, bus and microbus in study section for future study. It helps to identify undesirable conditions such as subsidy, traffic mobility and safety for SajhaYatayat, bus and microbus in study section and other section for future study, and help to diagnose their causes. It can help identify changes that are occurring with period i.e. trend analysis. It allows decision maker of public transport to set specific targets to achieve.

\section{ACKNOWLEDGEMENTS :}

Deepest thanks to all the helping hands without which this work would not have been completed. This research is dedicated to all the people affected from COVID19 and hope the world is going to come over this problem. Great Salutation to medical professionals and security people.

\section{REFERENCES :}

[1] Parthasarathi P., Levinson D., Hochmair H. (2013) Network Structure and Travel Time Perception. PLOS ONE 8(10): e77718. https://doi.org/10.1371/journal.pone.0077718

[2] SajhaYatayat, (2011). https://walkeasyktm.wordpress.com/2011/12/20/revival-of-sajha-yatayatsajha-buses-to-ply-valley-roads-in-four-months/ accessed on 14 September 2020.

[3] Pandey, N. (2014). Assessment of financial modality of Kathmandu -Kulekhani - Tunnel highway. M. Sc. Pokhara University.

[4] Roux, Y. (2013). A Comparative study of Public Transport systems in Developing Countries, Masters, University of Cape Town.

[5] SanyuktaYatayat http://samyuktayatayat.com.np/customer/samyukta.xhtml accessed on 13 September 2020.

[6] Tranter, M. (2013). Annual bus statistics: England 2014/15. December. https://www.gov.uk/ government/ uploads/system/uploads/attachment data/file/485296/annual-bus-statistics-yearending-march-2015.pdf

[7] Odufuwa and Olufemi B., 2012, Gender and Safety in Public Transportation: An Explorative Study in Lagos Metropolis, Nigeria. Master course in urban management and development. Erasmus University, Rotterdam.

[8] Anon. (2010). Measuring Public Transport Accessibility Levels. PTALs: Summary. April 2010, 18. London, Transport for London. Available through Website: webpid.elgin.gov.uk (Accessed date 22 March 2020).

[9] Armstrong-Wright, A. (1987). Urban transport-the World Bank, a review, In: Heraty, M.J. (Ed): Developing world transport. Grosvenor Press International, London.

[10] Ryan R, 2008. Corporate Finance and Valuation London, 2006. Thomson Learning, Followed by Available through: $\quad$ www.accaglobal.com/pubs/students/publications/student/archive/ sa apr08_ryan2.pdf (Accessed date 19 March 2020),

Anjay Kumar Mishra, et al, (2020); www.srinivaspublication.com 
[11] Kumar, P. P., Parida, M., \& Swami, M. (2013). Performance Evaluation of Multimodal Transportation Systems. Procedia - Social and Behavioral Sciences, 104(December), 795804. https://doi.org/10.1016/j.sbspro.2013.11.174.

[12] Abreha, D. A. (2007). Analysing Public Transport Performance Using Efficiency Measures and Spatial Analysis; the case of Addis Ababa, Ethiopia. Combustion Science and Technology, 21(5-6), 1-49. https://doi.org/10.1080/00102208008946937

[13] Turner, J. (2013). Assessment of a possible post-MDG Urban Transport Indicator., UK, Department for International Development (DFID). Available through: http://dx.doi.org/10.12774/eod_hd032b.jun2013.turner. (Accessed date 21 March 2020).

[14] Øvstedal G, Øderud A.T., (2011). Accessibility indicators for urban public transport, Europe, Mediate Followed by Available through: http://www.mediateproject.eu/fileadmin/Deliverables/Accessibility_indicators_for_urban_public_transport_Final.pd f (Accessed date 22 March 2015).

[15] Vuchic, V. R. (2005). Urban Transit: Operations, Planning and Economics. Book published by John Wiley \& Sons. ISBN: 978-0-471-63265-8, pp. 664

[16] Brussels. (2001). Transport Safety Performance Indicators. http://etsc.eu/wpcontent/uploads/2003 transport safety stats eu overview.pdf

[17] Yaakub, N., \& Napiah, M. (2011). Quality of Service and Passenger's Perception - A Review on Bus Service in Kota Bharu. International Journal of Civil \& Environmental Engineering IJCEEIJENS, 11(05), 1-9. Available through: http://www.ijens.org/vol_11_i_05/114504-05-8282ijcee-ijens.pdf.

[18] Udas, S. (2012). Public Transport Quality Survey. Clean Air Network Nepal (CANN) and Clean Energy Nepal (CEN).

[19] Nepal, Shiv Madi (2005). Mass transit opportunity study within the ring road of Kathmandu valley. Master of Science in urban planning. Tribhuvan University, Institute of engineering Pulchowk campus, Lalitpur. 